\title{
Dholuo Kincepts in Western Kenya
}

\author{
Washington Onyango-Ouma and Jens Aagaard-Hansen \\ University of Nairobi and University of the Witwatersrand
}

\begin{abstract}
The Luo are a Nilotic people living in western Kenya, north-eastern Tanzania and in western Uganda. Their language, Dholuo, forms part of the Western Nilotic group of languages. This article presents the traditional kincepts (kinship terminology) of the Luo people as described by elders living in Central Sakwa location, Siaya County, western part of Kenya. The kincepts for consanguine as well as affine relatives in up to three ascending and five descending generations are described. The paper applies a combined linguistic and anthropological approach. Linguistically, the terms are analysed in relation to current Dholuo vocabulary, grammar and modes of expression. Anthropologically, the Luo kinship rules of patrilineality and virilocality are considered. The domain of kincepts is a research field bringing together linguistics, anthropology and history. It contributes to the inquiry of diachronic linguistics, which can provide insights on the development and interaction of related languages as well as population groups' migratory patterns not least in parts of the world where written historical sources are scarce.
\end{abstract}

Keywords: Anthropology, Dholuo, History, Kenya, Kincepts, Kinship Terminology, Luo

\section{Introduction}

Dholuo is part of the Western Nilotic group of languages, and more specifically the Southern Lwoo group that also comprises of Acholi, Adhola, Lango and others that share morphological features of: 1) presence of derived locative nouns that are marked with a prefix $p a-, 2)$ paired prefixed singular-plural genders on derived nouns, and 3) absence of two markers for general singulars (-no, -do) (Storch 2014: 3-8). Within the linguistic literature certain aspects of Dholuo have been investigated including existence of passive (Ochola 1999), downdrift and downstep (Tucker \& Creider 1975), personal pronouns and object markers (Dalgish 1977), encoding of polar questions (Ojwang' 2008), codeswitching between Dholuo and English (Ochola 2006) and the role of the extended projection principle in Dholuo (Cable 2012).

Previous scholarly work has examined aspects of Dholuo kincepts (kinship terminology). Christie Jr. (1983) explored the use of possession and pressures to make it conform to use of possession in Dholuo in general, and Waligórski (1968) provided an overview of some key Dholuo kincepts in relation to Luo social life. Recently Storch (2014) published an extensive grammar of the related Luwo language (which is a member of the Northern Lwoo group of languages) including a section on Luwo kinship terminology.

According to Crazzolara (1950), the Luo had their origin together with the Shilluk, Nuer, Dinka and many other Nilotic groups in the "cradle land" west of Bahr-el-Jebel in what is now the Republic of South Sudan. The historian, Bethwell Ogot (1967, 2009), is the main authority on Luo migration in Kenya. He described how since approximately the year 1500, independent groups of Luo people came from the North and gradually settled in various parts of the former Nyanza Province in western Kenya. The land was already inhabited and the newcomers usually took the land by force, whereby the peoples already in place were either assimilated or sent on new migration 
themselves. Thus, many of the original "Nilo-Hamitic" (later termed "Para-Nilotic" (Whiteley 1974)) and Bantu peoples in Nyanza were assimilated by the Luo (Ogot 1967, 2009). Apart from Kenya, there are Luo people in north eastern Tanzania and western Uganda. Furthermore, the Jop'Adhola ethnic group in eastern Uganda is closely related to the Luo culturally and linguistically. Traditionally the Luo are patrilineal, virilocal and polygynous (Ocholla-Ayayo 1976, Nyambedha 2006).

Early anthropologists considered studying kinship terminology an essential part of cultural and social anthropology. As a result initial studies of kinship explored how various social practices evolved (Maine 1861, Morgan 1870, Rivers 1924, Radcliffe-Brown 1931, Allen 1989). Notable anthropological studies of kinship in Africa came from Fortes (1949), Radcliffe-Brown and Forde (1950) and Evans-Pritchard (1951, 1965). The study of kinship is also significant for later anthropology since theories of human behavior have been tested by kinship analysis (Schusky 1965).

The present article provides a comprehensive description of the system of Luo kincepts (kinship terminology), as conceptualized by the elders in the Nyang'oma area of Central Sakwa location in Siaya County in western Kenya, representing a 'traditional' ethnographic perspective on anthropological linguistics. The domain of kincepts is a rich research field bringing together linguistics, anthropology and history. It contributes to diachronic linguistic inquiries on the development and interaction of related Nilotic languages and past migratory patterns of ethnic groups.

\section{Methodology}

The fieldwork for this qualitative, empirical, descriptive study was conducted between 1996 and 2000 in the Nyang'oma area of Central Sakwa location in Siaya County in western Kenya. Data were generated by semi-structured interviews with 11 key informants aged 65 and above, 5 males and 6 females. The interviews were conducted in Dholuo of which the first author is a native speaker.

\section{Luo Kinship Terminology}

The consanguine Luo kinship terminology is outlined in Table 1 with reference to Figure 1a and $1 \mathrm{~b}$. The terms distinguish between the genders and generally also between generations. The exceptions are in generations $-3,-4$ and -5 where the terms are used for both genders:

(1) a. dhokliunda/thukliunda

dhoklluunda /thukliuunda ${ }^{1}$

great grandchild /great grandchild

'great grandchild'

b. mbieny

mbIreny

great great grandchild

'great great grandchild'

\footnotetext{
${ }^{1}$ The data are presented according to the established orthographic system applied by Storch (2014), though tonal data and close phonetic transcription are not included.
} 
c. chino/obuny

chIno/sbuuny

great great great grandchild

'great great great grandchild'

Seen from the position of EGO, the co-wives of the biological mother in generation +1 are referred to as:

(2) mama matin

mama matIIn

mother small

'step mother'

Hence, they are in the same category as the biological mother, but the addition of matin 'small' indicates the difference. At the same level, the patrilineal structure of Luo kinship appears in the difference between the terms:

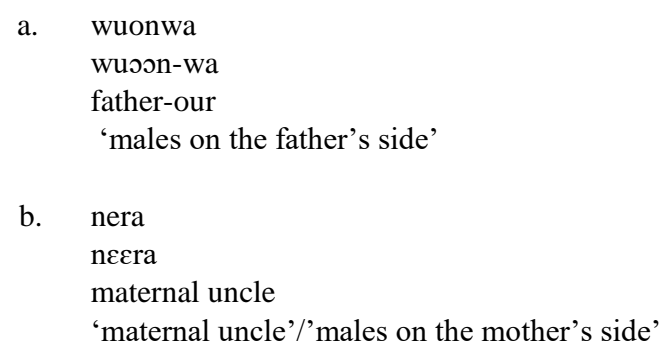

The suffix -wa (as shown in 3a) is a general indication of genitive first person plural (our). Seen from the EGO's position, all males and females in generation 0 are referred to as 'our brothers' or 'our sisters' respectively without distinguishing which of them is the child of the biological mother.

Min means 'mother', and is often used as a prefix to a name meaning 'the mother of so and so'. The prefix, nya- (plural nyi-), is a diminutive form (Omondi 1982:81-83), but can also indicate 'daughter of '.

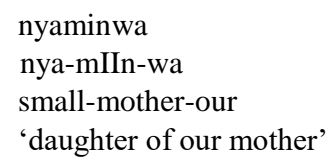

The term mahie (which can be translated as 'real') is added to some of the terms in order to indicate a direct blood relationship, e.g.:

$$
\begin{array}{lll}
\text { a. mama } & \text { mahie } \\
\text { mama } & \text { mahII } \\
\text { mother } & \text { real } \\
\text { 'biological } & \text { mother' (as opposed to her sisters) }
\end{array}
$$




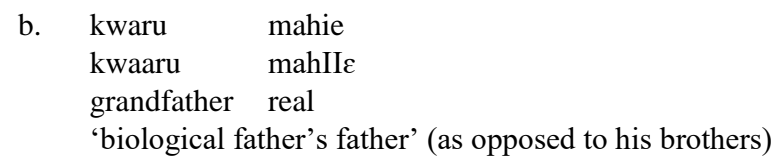

Table 1: Terminology for consanguine relatives referring to Figure 1a and $1 \mathrm{~b}$.

\begin{tabular}{|l|l|}
\hline Generation & Both male and female ego \\
\hline+3 & $1,3-4,6-7,9-10,12:$ dani \\
& $2,5,8,11:$ kwaru \\
\hline+2 & $1,5,7,10,12,16,18,20:$ kwaru \\
& $2,6,8,11:$ waya \\
& $13,17,19,22:$ dani \\
& $4,15:$ kwaru mahie \\
& $3,14:$ dani matin \\
& $9,21:$ dani mahie \\
\hline+1 & $1:$ mama/minwa matin \\
& $2,5:$ baba/wuonwa \\
& $3,6:$ waya \\
& $4:$ baba/wuonwa mahie \\
& $7,9:$ nera \\
& $8,11:$ mama/minwa \\
& $10:$ mama/minwa mahie \\
\hline 0 & $1,3:$ owadwa/omera \\
& $2,4:$ nyaminwa/nyamera \\
\hline-1 & $1,5:$ wuoda \\
& $2,6:$ nyara \\
& $3:$ wuoda mahie \\
& $4:$ nyara mahie \\
\hline-2 & $1-4,9-12:$ nyikwaya \\
& $5-8:$ nyikwaya mahie \\
\hline-3 & dhokliunda/thukliunda \\
\hline-5 & mbieny \\
\hline & chino/obuny \\
\hline
\end{tabular}


308

Dholuo Kincepts in Western Kenya

Figure 1a: Consanguine.

igure 1a: Luo Kinship

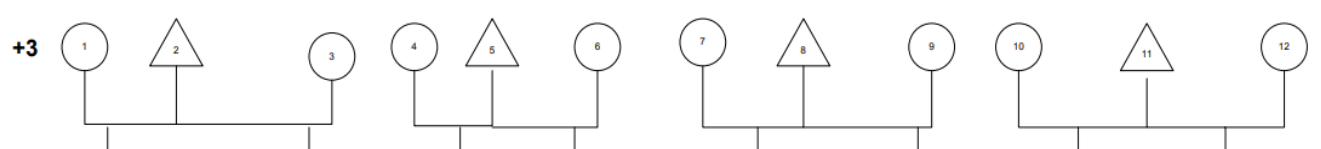
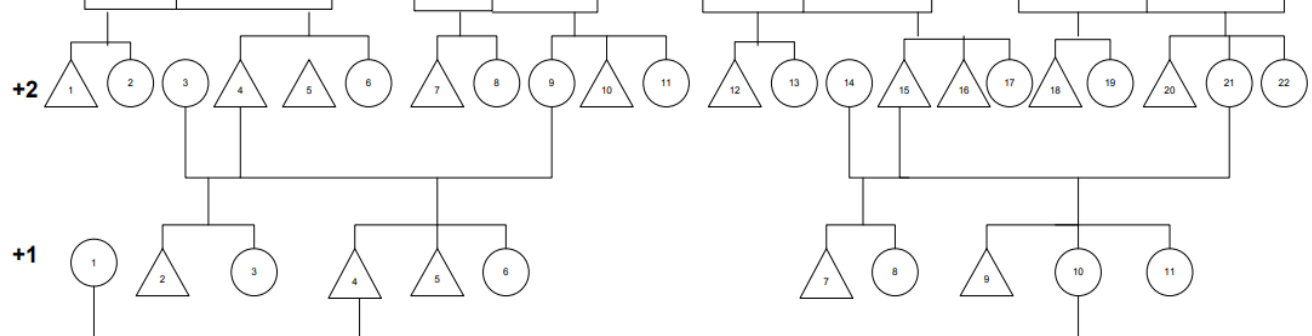

- $\Delta \sigma \Delta$

4

Figure 1b: Consanguine.

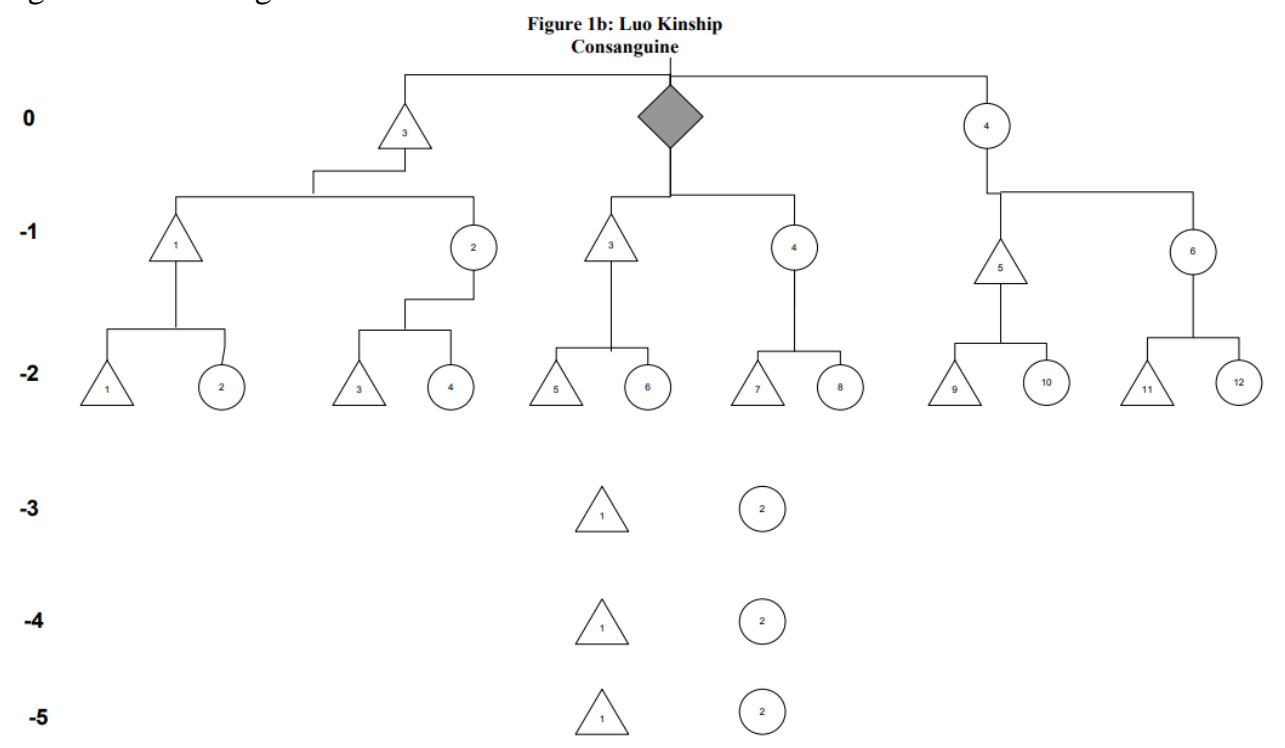


Below a series of Tables $(2-8)$ and Figures $(2 a-8 b)$ visualising the Luo kinship terminology for the affinal kin (in-laws).

Table 2: Terminology for ego's in-laws referring to Figures 2a and 2b.

\begin{tabular}{|l|l|l|}
\hline Generation & Male ego & Female ego \\
\hline+2 & $1,3:$ kwaru & $1,3:$ kwaru \\
& $2,4:$ dani & $2,4:$ dani \\
\hline+1 & $1,4,6$ : jaduong' & $1:$ nera \\
& $2:$ mara mahie & $2:$ dani mahie (wuonodwa) \\
& $3,5:$ mara & 3: dani \\
& $7:$ waya & $4:$ kwaru mahie \\
& & $5:$ dani matin \\
& & $6:$ kwaru \\
& & $7:$ waya \\
\hline 0 & $1:$ chiega (jaoda) & $1:$ chuora (jaoda) \\
& $2:$ yuora & $2:$ waya \\
& $3:$ ori & $3:$ yuora \\
\hline-1 & $1-4:$ nyathina & $1-4$ : nyathina \\
\hline
\end{tabular}

Figure 2a: Ego's In-laws, Male Ego.

Figure 2a: Luo Kinship

Ego's In-laws. Male Ego

$+2$

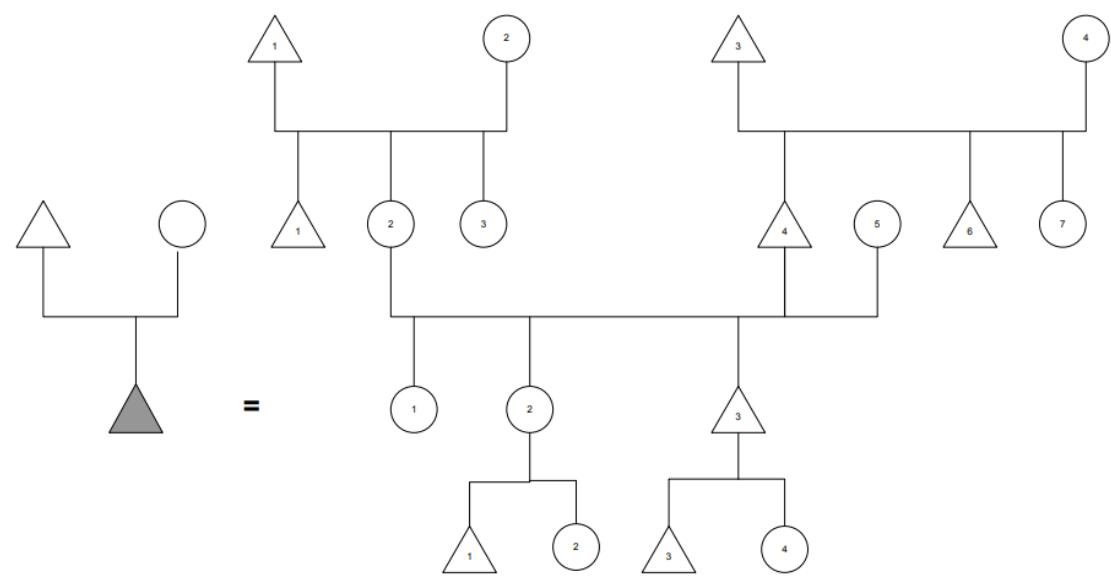

$-1$ 
Figure 2b: Ego's In-laws, Female Ego.

Figure 2b: Luo Kinship

Ego's In-laws. Female Ego

$+2$

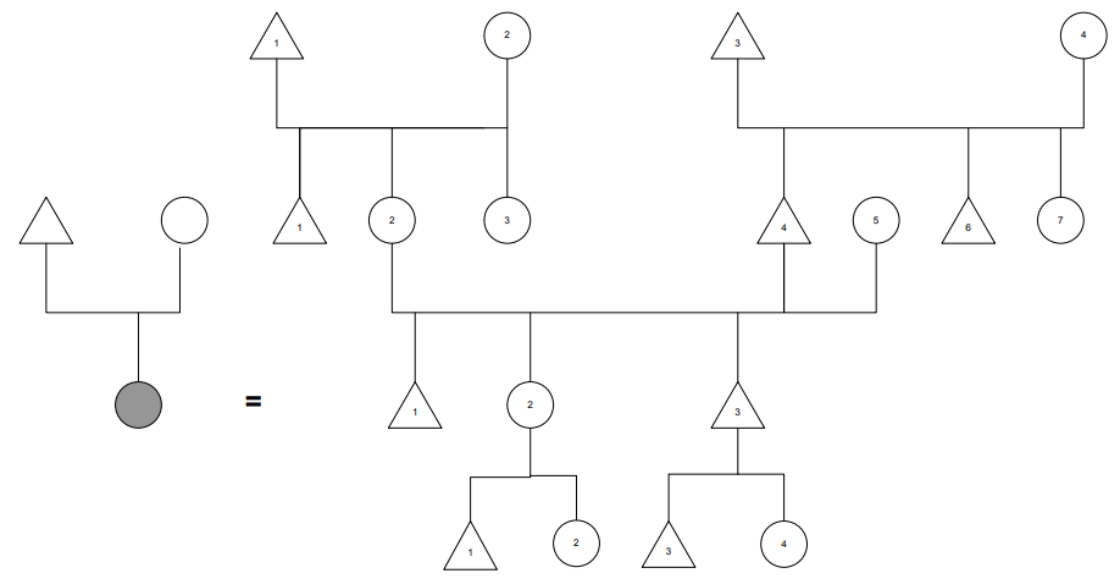

$-1$

Table 3: Terminology for brother's in-laws referring to Figures 3a and $3 \mathrm{~b}$

\begin{tabular}{|l|l|l|}
\hline Generation & Male ego & Female ego \\
\hline+2 & $1,3:$ kwaru & $1,3:$ kwaru \\
& $2,4:$ dani & $2,4:$ dani \\
\hline+1 & $1,4,6:$ jaduong' & $1,4,6:$ jaduong' \\
& $2,3,5:$ mara & $2,3,5:$ mara \\
& 7: waya & $7:$ waya \\
\hline 0 & 1-2: yuora & $1-2:$ yuora \\
& 3: ori & 3: ori \\
\hline
\end{tabular}

Figure 3a: Brother's In-laws, Male Ego.

Figure 3a: Luo Kinship Brother's In-laws. Male Ego

$+2$

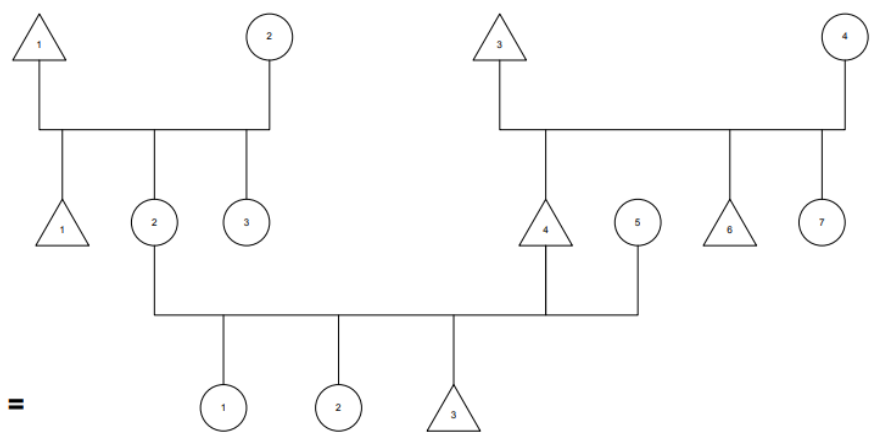

0

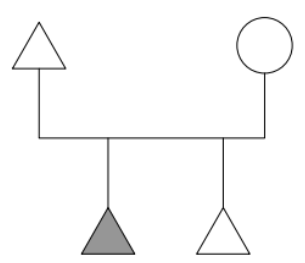


Figure 3b: Brother's In-laws, Female Ego.

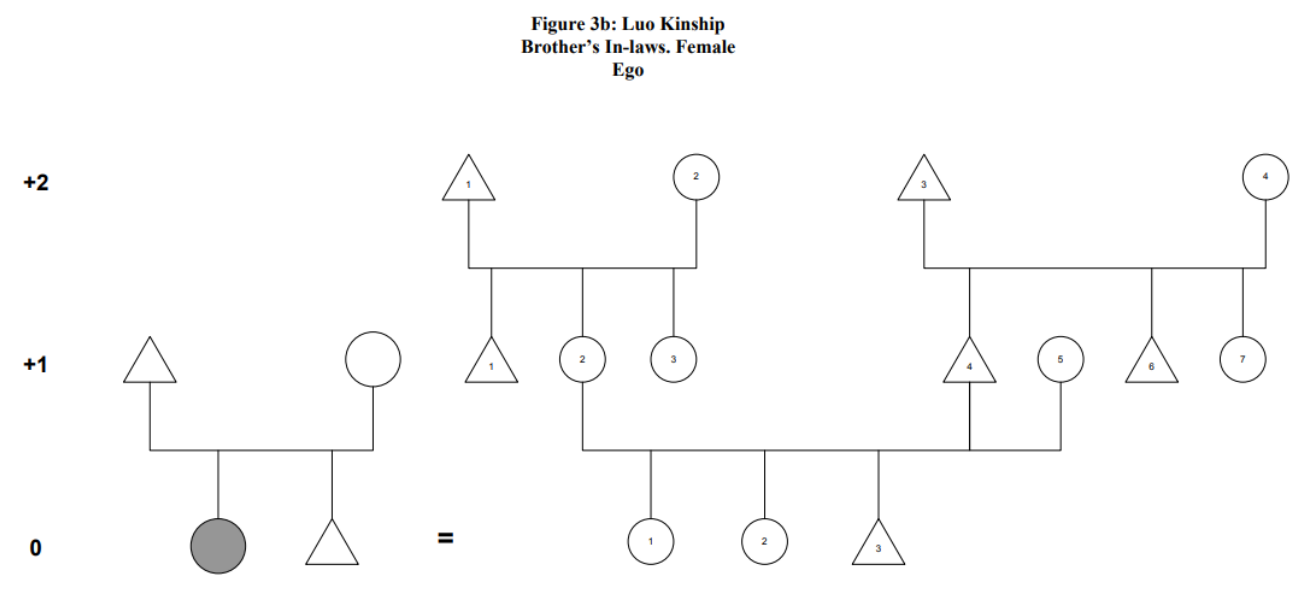

Table 4: Terminology for sister's in-laws referring to Figures 4a and 4b

\begin{tabular}{|l|l|l|}
\hline Generation & Male ego & Female ego \\
\hline+2 & $1,3:$ kwaru & $1,3:$ kwaru \\
& $2,4:$ dani & $2,4:$ dani \\
\hline+1 & $1:$ nera & $1:$ nera \\
& $2,3,5:$ dani & $2,3,5:$ dani \\
& 4, 6: kwaru & $4,6:$ kwaru \\
& 7: waya & $7:$ waya \\
\hline 0 & 1-3: ori & $1-3:$ yuori \\
\hline
\end{tabular}

Figure 4a: Sister's In-laws, Male Ego.

$+2$

$$
\begin{aligned}
& \text { Figure 4a: Luo Kinship } \\
& \text { Sister's In-laws. Male Ego }
\end{aligned}
$$

$+1$

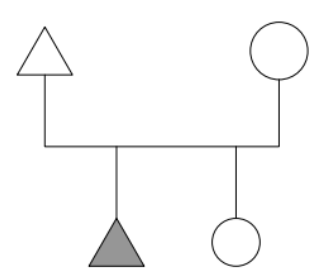

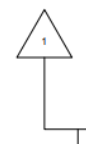
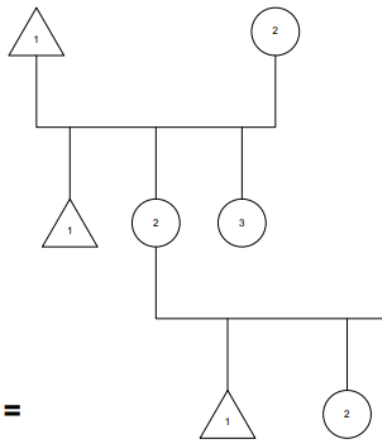

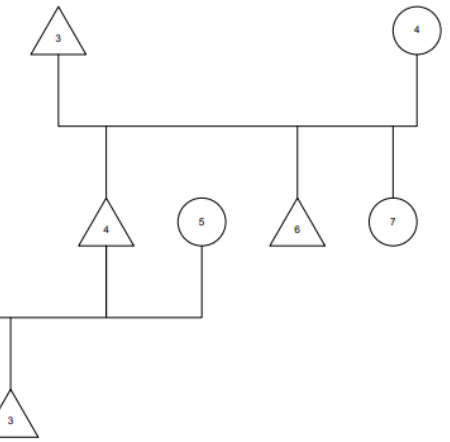


Figure 4b: Sister's In-laws, Female Ego.

Figure 4b: Luo Kinship

Sister's In-laws. Female

Ego

$+2$

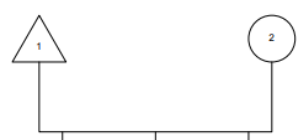

$+1$
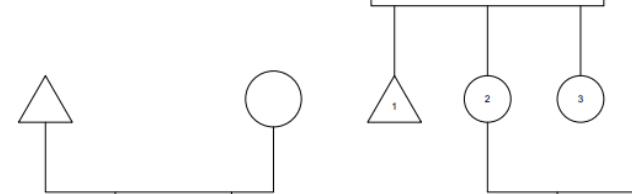

(1)

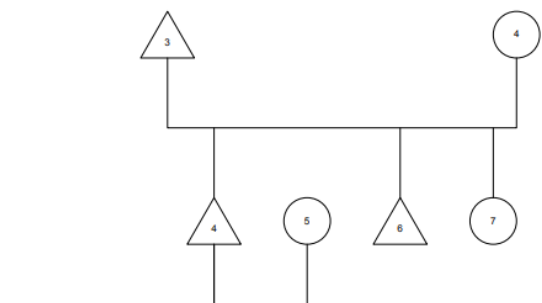

0

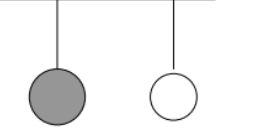

$=$

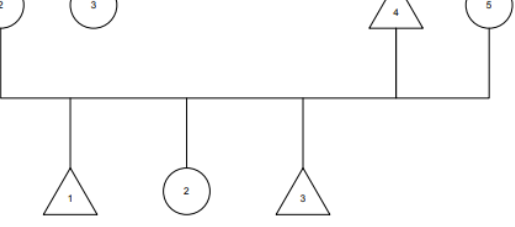

Table 5: Terminology for son's in-laws referring to Figures 5a and 5b.

\begin{tabular}{|l|l|l|}
\hline Generation & Male ego & Female ego \\
\hline+1 & $1,3:$ wuonwa & $1,3:$ wuonwa \\
& $2,4:$ minwa & $2,4:$ minwa \\
\hline 0 & $1,3,5,6,7:$ nyawanda & $1,3,5,6,7:$ nyawanda \\
& $2,4:$ nyawanda mahie & $2,4:$ nyawanda mahie \\
\hline-1 & $1,2:$ mara & $1,2:$ nyara \\
& $3:$ ori & $3:$ ori \\
\hline
\end{tabular}

Figure 5a: Son's In-laws, Male Ego.

Figure 5a: Luo Kinship

Son's In-laws. Male Ego

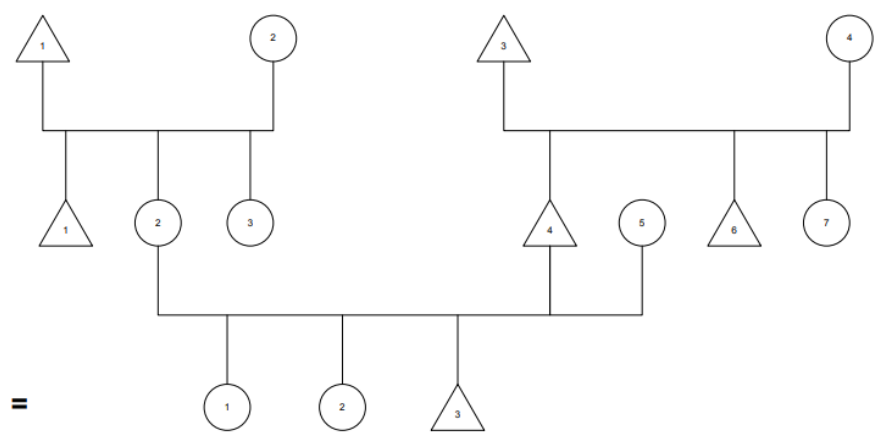

$+1$
0

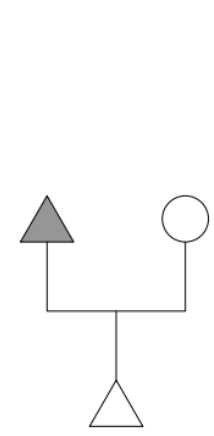

$-1$ 
Figure 5b: Son's In-laws, Female Ego.

Figure 5b: Luo Kinship

Son's In-laws. Female Ego

$+1$

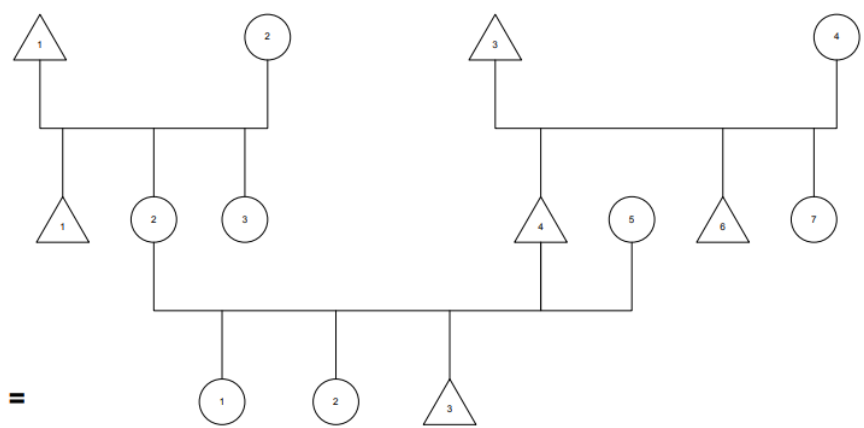

0

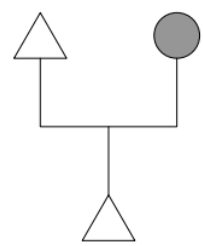

Table 6: Terminology for daughter's in-laws referring to Figures 6a and $6 \mathrm{~b}$.

\begin{tabular}{|l|l|l|}
\hline Generation & Male ego & Female ego \\
\hline+1 & $1,3:$ wuonwa & $1,3:$ wuonwa \\
& $2,4:$ minwa & $2,4:$ minwa \\
\hline 0 & $1,3,5,6,7:$ nyawanda & $1,3,5,6,7:$ nyawanda \\
& $2,4:$ nyawanda mahie & $2,4:$ nyawanda mahie \\
\hline-1 & $1,3:$ ori & $1,3:$ ori \\
& $2:$ nyara & $2:$ nyara \\
\hline
\end{tabular}

Figure 6a: Daughter's In-laws, Male Ego.

Figure 6a: Luo Kinship

Daugther's In-laws. Male

Ego

$+1$

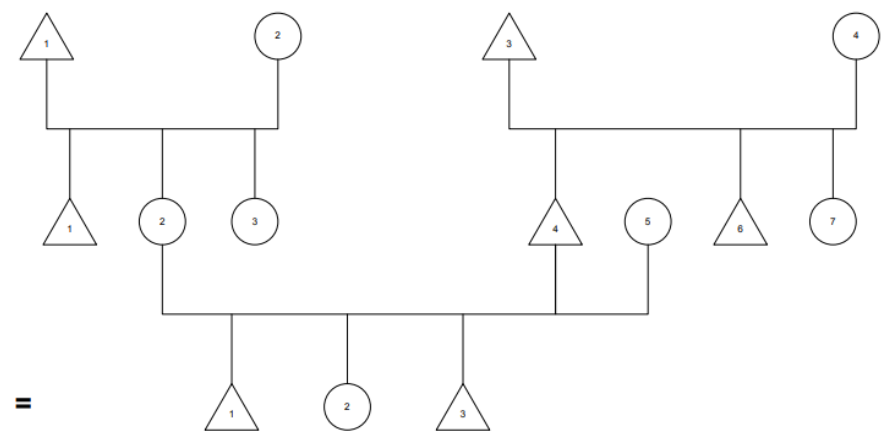

0

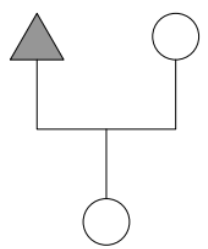

$=$ 
Figure 6b: Luo Kinship. Daughter's In-laws, Female Ego.

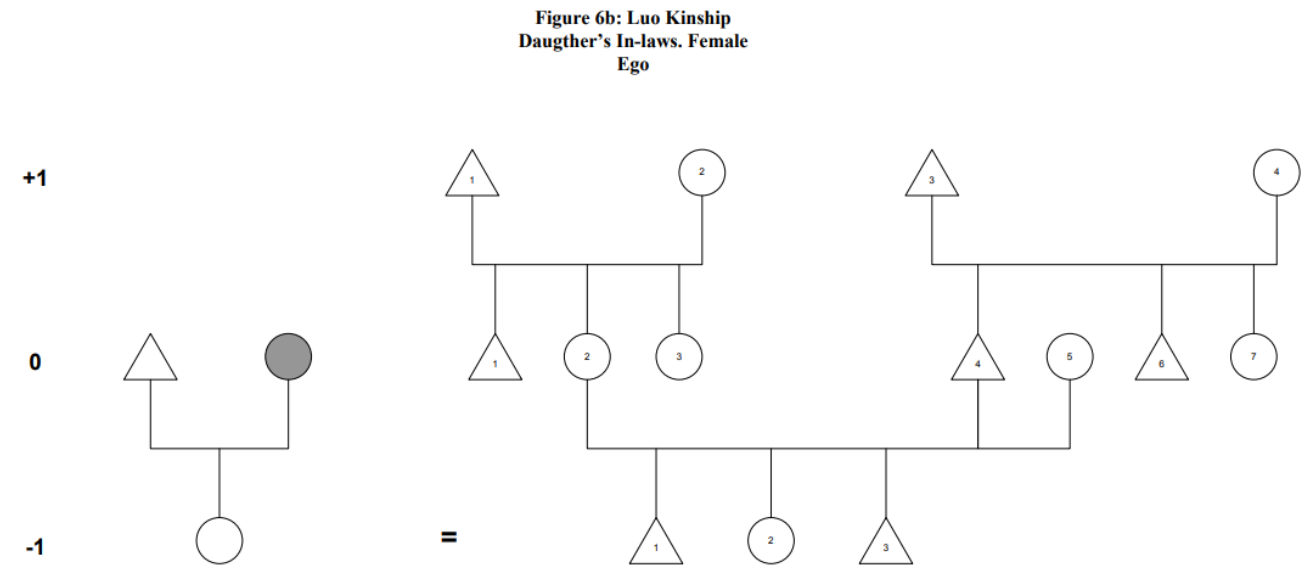

Table 7: Terminology for grandson's in-laws referring to Figures 7a and 7b.

\begin{tabular}{|l|l|l|}
\hline Generation & Male ego & Female ego \\
\hline 0 & $1,3:$ owadwa/nyawana & $1,3:$ owadwa/nyawana \\
& $2,4:$ nyaminwa/nyawana & $2,4:$ nyaminwa/nyawana \\
\hline-1 & $1,4,6:$ wuoda/nyawana & $1,4,6:$ wuoda/nyawana \\
& $2,3,5,7:$ nyara/nyawana & $2,3,5,7:$ nyara/nyawana \\
\hline-2 & $1,2,3:$ nyakwara & $1,2,3:$ nyakwara \\
\hline
\end{tabular}

Figure 7a: Grandson's In-laws, Male Ego.

Figure 7a: Luo Kinship Grandson's In-laws. Male Ego
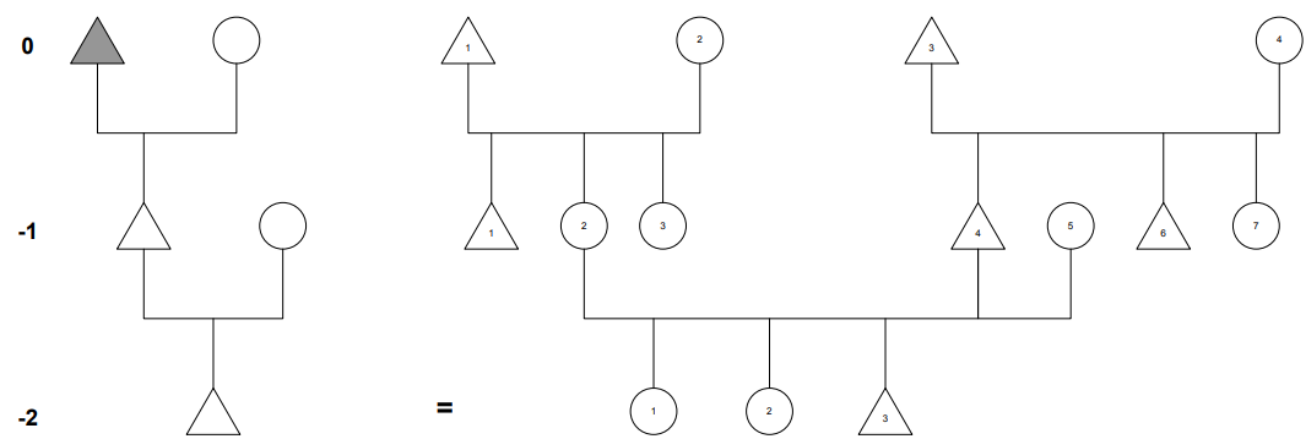
Figure 7b: Grandson's In-laws, Female Ego.

Figure 7b: Luo Kinship

Grandson's In-laws. Female

Ego
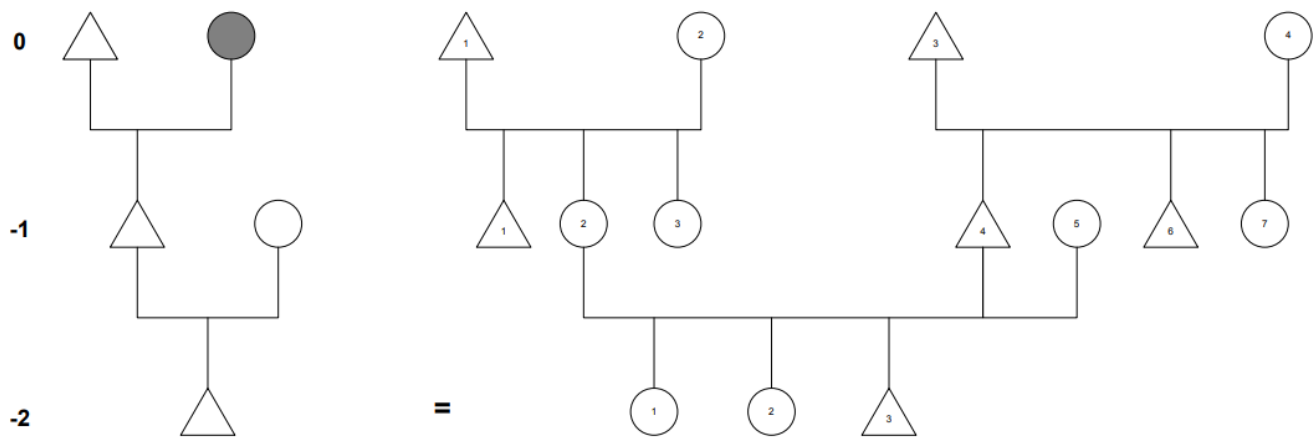

Table 8: Terminology for granddaughter's in-laws referring to Figures 8a and 8b.

\begin{tabular}{|l|l|l|}
\hline Generation & Male ego & Female ego \\
\hline 0 & $1,3:$ owadwa/nyawana & $1,3:$ owadwa/nyawana \\
& $2,4:$ nyaminwa/nyawana & $2,4:$ nyaminwa/nyawana \\
\hline-1 & $1,4,6:$ wuoda/nyawana & $1,4,6:$ wuoda/nyawana \\
& $2,3,5,7:$ nyara/nyawana & $2,3,5,7:$ nyara/nyawana \\
\hline-2 & $1,2,3:$ nyakwara & $1,2,3:$ nyakwara \\
\hline
\end{tabular}

Figure 8a: Granddaughter's In-laws, Male Ego.

Figure 8a: Luo Kinship

Granddaugther's In-laws.

Male Ego

\section{0}

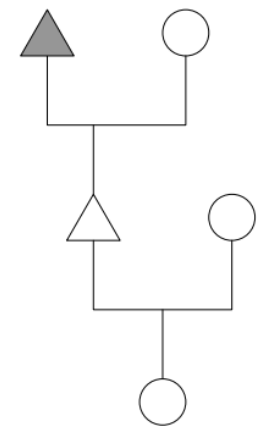

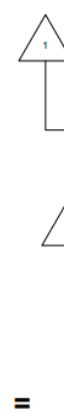

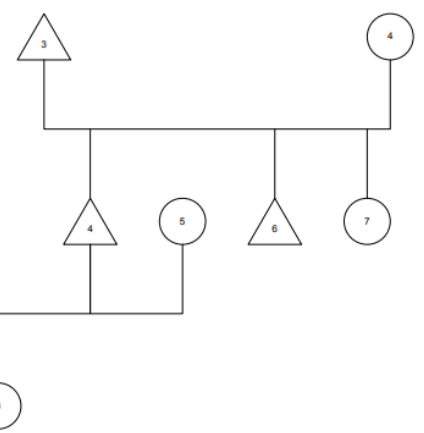


Figure 8b: Granddaughter's In-laws, Female Ego.

Figure 8b: Luo Kinship Granddaugther's In-laws. Female Ego

$\cdot$

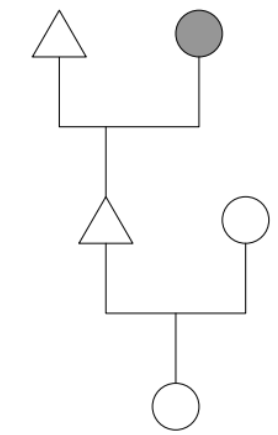

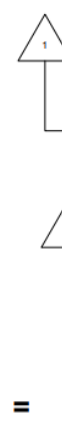

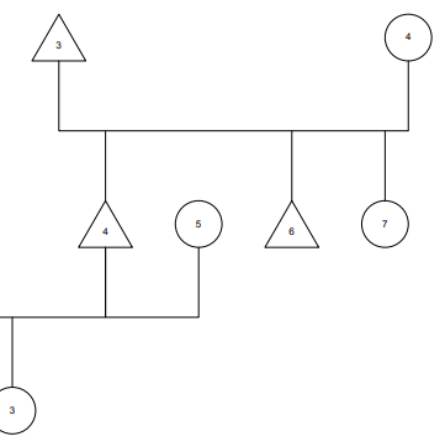

The prefix ja- (plural jo-) refers to a person in Table 3, whereas the adjective duong' (big) indicates a big person, not in the physical sense but in a honorific way (Omondi 1982:99), e.g.:

(6)

$$
\begin{aligned}
& \text { jaduong' } \\
& \text { ja-duoon } \\
& \text { person-big } \\
& \text { 'big person/elder' }
\end{aligned}
$$

The consanguine terminology for 'our father' ( $8 \mathrm{a}$ ) and 'our mother' ( $8 \mathrm{~b})$ below also apply to 'father'in-law' and 'mother-in-law' within the affinal system.
a. wuonwa
wuosn-wa
father-our
'our father'
b. minwa
mIIn-wa
mother-our
'our mother'

The use of the morpheme, nya-, indicating 'small' (see example 4) is also used in the following examples:

(8)

a. nyakwara (Table 2)

nya-kwaar-a

small-grandfather-mine

'my grandchild' (- 2 generation)

b. nyathina (Table 7)

nya-thIIn-a

small-small-mine

'my small one'/'my child' (-1 generation)

However, this rule does not apply in the case of: 
(9)
a. nyawanda
nyawaand-a
in law-mine
'my in-law'
b. nyawana
nyawaana
inlaw
'parents of child's spouse' (a special term for two adults whose children are married to each other)

Notably, many of the consanguine terms are used for the equivalent in-law positions. One would have expected a distinction due to the fact that the Luo are patrilineal. However, a marriage forms a bridge that connects two extended families, and the terminology used for the affines is framed based on the two individuals as the reference point on both sides.

None of the traditional ethnographic kinship frameworks apply precisely to the Dholuo terminology. The Dholuo system differs from the Hawaiian type because the former's kincepts are more differentiated at the levels from +2 to -2 , both included. This is not surprising, as the Hawaiian type is not found in societies with unilateral descent groups such as the Luo. The Dravidian/Iroquois typology, which emphasizes a differentiation between 'parallel relatives' and 'cross relatives', and the Crow/Omaha typology, which refers to a line of matrilineally related men and patrilineally related women respectively are also very different from the Dholuo system (Keesing 1975).

\section{Traditional Luo kincepts as a contribution to comparative anthropological linguistics}

The present article has provided a comprehensive description of the system of Luo kincepts as they are perceived in the Nyang'oma area of Central Sakwa location, Siaya County in western Kenya. A number of fairly old informants have provided coherent data on kinship terms that are now shared with the linguistic and anthropological communities. This adds to the existing examples of scholarly work within this field (Waligórski 1968; Christie Jr. 1983). Waligórski's (1968) fieldwork was conducted in Alego, which is situated about 30 kilometers from Nyang'oma where the present study was conducted, and though many of the kincepts are identical, Waligórski does not display the data comprehensively according to generations. The work of Christie Jr. (1983) is based on a single informant, the origin of whom is not revealed. The paper focuses on singular and plural possessors in relation to kincepts and analyzes the trend of number neutralization in Dholuo as compared to related Western Nilotic languages as well as the adjacent Bantu languages in western Kenya.

The attempts to describe the phylogenetic development of the Nilotic languages alongside the migratory patterns of the peoples that are presently spread out over large areas of eastern Africa go back to the early work of various groups of Christian missionaries about a century ago (St. Joseph Society 1920; Crazzolara 1950). Subsequently, other contributions have been made. One of anthropology's founding fathers, Evans-Pritchard (1951, 1965), was a protagonist for the benefits of including historical perspectives in anthropology. He studied the inter-relations and origins of ethnic groups in southern Sudan as well as east Africa, which are the areas of origin and destination respectively of migrations of many Western Nilotic peoples. The comparison of the Mberidi and the Mbegumba is a case in point, including wordlists of Shilluk, Luo and Mberidi (1931).

Number marking and noun categorization constitute a language domain with large variation from absence to a high degree of complexity. Dimmendaal (2000:214) describes "formal and semantic properties of this system from synchronic and diachronic points of view and explains 
its historical relative stability in Nilo-Saharan." The linguistic historical perspective on number inflection systems in Western Nilotic languages is further emphasized in the work of Storch (2003:88), who demonstrates that the "history of language contact and the understanding of linguistic areas in the Western Nilotic zone are of crucial importance." Thus, number marking and noun categorization is an important domain for comparative linguistics and diachronic analyses.

Kinship terminology has also been studied by prominent linguistic scholars. Allen (1989:178) suggests an evolutionary hypothesis for kinship terminologies where the general trend from prehistory till now is in the direction of zero-equation terminologies. Taking the American kinship system as a point of departure, Saltarelli and Durbin (1967) investigate the interaction of linguistic structures and kinship structures as a means of contributing to a comprehensive theory of semantics. Kuznecov (1974) provides a typology for comparison of the semantic field of consanguine relationships based on four languages (English, Danish, French and Spanish) and comprising the variables: 'seniority by generations', 'the degree of collateral kinship', 'sex' and 'direction of kinship'.

Ardener (1954:85) provides a conspicuous case of kinship terminology among a group of Southern Ibo in Eastern Nigeria showing an "extreme degree of dialect variation" as well as "local variation in details of the kinship organization itself". This serves as an important reminder that comparative analytical endeavors are not only between 'monolithic' and well-defined languages, though that is complicated enough in its own right especially in a historical perspective. It is further complicated by internal variations within the various languages.

Thus, we contend that the domain of kincepts is a rich research field bringing together linguistics, anthropology and history, and opening new angles of inquiry. Comparative studies on kincepts of related languages such as Acholi and Lango as well as more distantly related Western Nilotic languages would provide an interesting field of research. Such studies, along the lines of what Storch (2003) did on number inflection systems, would allow a diachronic linguistic perspective on the development and interaction of these languages. The work of Allen (1989), Saltarelli and Durbin (1967) and Kuznecov (1974) could serve as theoretical and methodological frameworks, but there is a need for empirical data from the relevant languages, such as the present description of Dholuo kincepts.

The present study has limitations. The data presented here were generated between 1996 and 2000. However, as the main point of this article is to describe traditional Luo kinship terminology, this does not decrease the validity and current relevance of the data. The fieldwork was conducted in one locality in northern Nyanza region and therefore it may not capture the variations among the Luo in different places in Kenya and not to mention Dholuo speaking people in Tanzania and Uganda. However, similar data from Waligórski (1968) in an area not too far away indicates a wider representativity. Future studies will show whether the kincepts in the present article represent Dholuo spoken elsewhere.

\section{Conclusion}

The present study has provided a comprehensive description of Dholuo kincepts in contemporary western Kenya. In addition, it contributes to the cross-disciplinary research field combining linguistics, anthropology and history in an effort to provide insights on the development and interaction of related languages and past migratory patterns especially in parts of the world where written historical sources are scarce. Furthermore, the data may find use outside academia especially 
among the practitioners of Luo culture who are struggling with loss of cultural knowledge against a background of modernization, urbanization and globalization.

\section{Acknowledgements}

We are grateful to the informants as well as the Nyang'oma community in general for embracing this and many of our other anthropological studies since 1993. We are grateful to DBL - Centre for Health Research and Development, University of Copenhagen for strongly facilitating the study financially and administratively. Also thanks to the Institute of Anthropology, Gender and African Studies, University of Nairobi for logistical facilitation and to linguistic scholars for valuable advice. We also acknowledge the invaluable assistance of the librarians who helped in accessing at times very hidden and old manuscripts. Last but not least thanks to anonymous reviewers and the editor for their guidance in the cross-disciplinary field between linguistics and anthropology.

\section{References}

Allen, N.J. 1989. The evolution of kinship terminologies. Lingua, 77: 173-185.

Ardener E.W. 1954. The Kinship Terminology of a Group of Southern Ibo. Africa. Journal of the International African Institute, 24(2): 85-99.

Cable, Seth. 2012. The optionality of movement and EPP in Dholuo. National Languages and Linguistic Theory. 30: 651-697.

Christie Jr., W.M. 1983. A note on the kinship system of Kenya Luo. Studies in African Linguistics, 14(3): 331-334.

Crazzolara, J.P. 1950. The Lwoo Part 1. Lwoo Migrations. Verona: Instituto Missioni Africane.

Dalgish, G.M. 1977. Personal pronouns, object markers, and syntactic evidence in Dho-luo. Studies in African Linguistics, 8(3): 101-120.

Dimmendaal, Gerrit. 2000. Number marking and noun categorization in Nilo-Saharan languages, Anthropological Linguistics 42: 2: 214-261.

Evans-Pritchard, Edward E. 1931. The Mberidi (Shilluk group) and Mbegumba (Basiri group) of the Bahr-el-Ghazal. Sudan Notes \& Records, 14, part 1: 15-48.

Evans-Pritchard, Edward E. 1951. Kinship and Marriage among the Nuer. Oxford: Clarendon.

Evans-Pritchard, Edward E. 1965. Luo Tribes and Clans. In: The Position of Women in Primitive Societies and Other Essays in Social Anthropology. Evans-Pritchard, EE (ed.), pp. 205-227. London: Faber and Faber Ltd.

Fortes, Meyer. 1949. The Web of Kinship among Tallensi. London: Oxford University Press

Keesing, Roger M. 1975. Kin groups and social structure. New York: Holt, Rinehart and Winston.

Kuznecov, A.M. 1974. On the typology of the semantic field of kinship terms. Linguistics, 12(125): $5-14$.

Maine, Henry S. 1861. Ancient Law. London: Murray.

Morgan, Lewis H. 1870. Systems of Consanguinity and Affinity. Washington, D.C.: Smithsonian Institution Contributions to Knowledge, 17: 218.

Nyambedha, Erick O. 2006. Children and HIV/AIDS. Questioning Vulnerability in Western Kenya. $\mathrm{PhD}$ thesis. Department of Anthropology, Faculty of Social Sciences, University of Copenhagen \& DBL - Institute for Health Research and Development.

Ochola, Eunita D.A. 1999. Is there a passive in Dholuo? Studies in African Linguistics, 28(1): 3148. 
Ochola, Eunita D.A. 2006. English Words and Phrases in Dholuo-English Codeswitching. Selected Proceedings of the $36^{\text {th }}$ Annual Conference on African Linguistics. Ed. Arasanyin F. and Pemberton, Michael A.: Somerville, MA; Cascadilla Proceedings Project, pp.208-220.

Ocholla-Ayayo, Andrev B.C. 1976. Traditional Ideology and Ethics among Southern Luo. Uppsala: The Scandinavian Institute of African Studies.

Ogot, Bethwell A. 1967. History of the Southern Luo. Vol.1 Migration and Settlement 1500-1900. Nairobi: East African Publishing House.

Ogot, Bethwell A. 2009. A History of the Luo-Speaking Peoples of Eastern Africa. Kisumu: Anyange Press Ltd.

Ojwang', B.O. 2008. Encoding polar questions in Dholuo. Studies in African Linguistics, 37(1): 6191.

Omondi, Lucia Ndong'a. 1982. The major syntactic structures of Dholuo. Berlin: Dietrich Riemer Verlag.

Rivers, William H.R. 1924. Social Organization. London: Kegan Paul, Trench \& Trubner.

Radcliffe-Brown, Alfred R. 1931. The Social Organization of Australian Tribes. Sydney: Oceania Monograph (1).

Radcliffe-Brown, Alfred R. and Daryll Forde (Eds). 1950. African Systems of Kinship and Marriage. London: Oxford University Press.

Saltarelli, M. and M. Durbin, 1967. A semantic interpretation of kinship systems. Linguistics, 5(33): 87-94.

Schusky, Ernest L. 1965. Manual for Kinship Analysis. New York: Holt, Rinehart and Winston.

St. Joseph's Society. 1920. A handbook of the Kavirondo language. Nairobi: Caxton Printing and Publishing Works.

Storch, Anne 2003. Dynamics of interacting populations: Language contact in the Lwoo languages of Bahr El-Ghazal. Studies in African Linguistics, 32(1): 65-93.

Storch, Anne 2014. A Grammer of Luwo. An anthropological approach. Amsterdam/Philadelphia: John Benjamin Publishing Company.

Tucker, A.N. \& Creider, C.A. 1975. Downdrift and downstep in Luo. Proceedings of the Sixth Conference on African Linguistics. OSU WPL 20.125-134.

Waligórski, A. 1968. Kinship terminology of the Luo. Africana Bulletin, 8: 57-63.

Whiteley, N.H. 1974. The Classification and Distribution of Kenya's African Languages, In: Whiteley, NH (ed) (1974) Languages in Kenya. Nairobi: Oxford University Press.

Washington Onyango-Ouma <onyango.ouma@uonbi.ac.ke>

Institute of Anthropology, Gender and African Studies

University of Nairobi, Nairobi. Kenya

Jens Aagaard-Hansen <anthropology@mail.tele.dk>

1) University of the Witwatersrand, Johannesburg, South Africa

SA MRC Developmental Pathways for Health Research Unit, Faculty of Health Sciences

2) Health Promotion, Steno Diabetes Center Copenhagen, Gentofte, Denmark 